\title{
ŁÓDZKI OŚRODEK HISTORIOGRAFICZNY. ŚRODOWISKO, BADANIA, DYDAKTYKA*
}

\section{Jolanta KOLBUSZEWSKA}

\section{ABSTRACT}

\section{LODZ HISTORIOGRAPHIC CENTER. COMMUNITY, RESEARCHES, DIDACTICS}

The article consists of three parts. It begins with a short characteristics of the lodz historiographic centre; the Author discusses the three generations of researchers who carried out research in the field at the University of Lodz (UE). The second part is devoted to characterizing the interests and research achievements of the current members of the Department of the History of Historiography and the Auxiliary Sciences of History. The doctors promoted in the recent years were also included. The final part of the article presents the courses in the history of historiography currently being held at the Institute of History, UE.

\section{KEYWORDS:}

history of historiography, methodology of history, the historiographic school of Lodz 
1.

Uniwersytet Łódzki ma bogate tradycje w badaniach z zakresu historii historiografii ${ }^{1}$ Związani z nim tuż po wojnie badacze, odegrali niezwykle istotną rolę w procesie emancypacji i rozwoju wspomnianej subdyscypliny, stworzeniu jej teoretycznych podwalin i zaplecza instytucjonalnego. W Instytucie Historii UŁ pracowały co najmniej trzy generacje badaczy specjalizujących się w historii historiografii. Do pierwszej, należeli: Marian Henryk Serejski², Józef Dutkiewicz ${ }^{3}$, Jan Adamus ${ }^{4}$ oraz Krystyna Śreniowska5. Serejski uznawany za „ojca polskiej historii historiografii” stworzył w Łodzi szkołę, której osiągnięcia wysoko ceniono, zarówno w kraju, jak i za granicą ${ }^{6}$. Podejmowane przezeń badania były rozległe i różnorodne, a celem jaki sobie stawiał, miało być nowe, nawiązujące do powojennych przeobrażeń w Polsce, ujęcie dorobku nauki i myśli historycznej ${ }^{7}$. Wypracowana przez Serejskiego koncepcja badawcza była kontynuowana oraz modyfikowana przez współpracowników i uczniów.

1 Zob. R. Stobiecki, Łódź jako ośrodek badań historiograficznych po 1945 r., „Rocznik Łódzki” 2003, T. 50, s. 31-44.

2 M. H. Serejski związany był z Łodzią od 1945 do 1965 roku. Współorganizował Instytut Historii UŁ, kierował Katedrą Historii Społecznej Starożytności i Średniowiecza, od 1952 r. Katedrą Historii Powszechnej. Związany był również z IH PAN, gdzie od 1953 roku kierował Zakładem Historii Historiografii a po jego rozwiązaniu od 1968 roku Komisją Historii Historiografii PAN oraz Zakładem Nauki i Techniki PAN; szerzej zob. J. Maternicki, Marian Henryk Serejski, w: Historycy warszawscy ostatnich dwóch stuleci, Warszawa 1986, s. 377-400; J. Kita, Marian Henryk Serejski (3 maja 1897-23 października 1975), w: Tenże, Luminarze nauki polskiej w Uniwersytecie Eódzkim 1945-2015, Łódź 2015, s. 227-230.

3 Jerzy Dutkiewicz (1903-1986) ukończył studia na Uniwersytecie Jagiellońskim, doktoryzował się w 1926 roku na podstawie pracy Austria wobec powstania listopadowego. Habilitację uzyskat tuż po wojnie, jej podstawa była rozprawa Francja a Polska w 1831 roku; szerzej zob. J. Kita, Józef Dutkiewicz (7 marca 1903-6 października 1986), w: tenże, Luminarze nauki polskiej..., s. 45-48.

4 Jan Adamus (1896-1962) uzyskał doktorat w roku 1927, habilitował się w 1933. Po wojnie związany z Uniwersytetem Łódzkim, od 1955 roku kierował Katedrą Powszechnej Historii Państwa i Prawa. Poza zagadnieniami z zakresu prawa, podejmował kwestie związane z teorią i metodologią historii, badał poglądy J. Lelewela oraz zjawisko monarchizmu i republikanizmu; zob.: Stownik biograficzny historyków tódzkich, red. J. Kita, R. Stobiecki, Łódź 2000, s. 11-13.

5 Krystyna Śreniowska (1914-2013), absolwentka historii i Studium Dyplomatycznego UJK (1937). Od 1945 r. aż do przejścia na emeryturę w 1986 r. związana była z Instytutem Historii Uniwersytetu Łódzkiego. Doktorat uzyskała w 1956 roku na podstawie pracy Stanisław Zakrzewski. Przyczynek do charakterystyki prądów ideologicznych $w$ historiografi polskiej 1893-1936 (1956). Habilitowała się w 1964 roku na podstawie dysertacji Kościuszko. Kształtowanie poglądów na bohatera narodowego 1794-1894; szerzej zob. R. Stobiecki, Prof. dr hab. Krystyna Śreniowska. Szkic do portretu, w: Jubileusz Profesor Krystyny Śreniowskiej, Łódź 2004, s. 5-12; Z. Romek, Krystyna Śreniowska (1914-2013), „Dzieje Najnowsze” 2014, nr 1, s. 278-282.

6 Na temat stworzonej przez M. H. Serejskiego szkoły historiograficznej pisała ostatnio J. Kolbuszewska, Aktualność dorobku „tódzkiej szkoły historiograficznej” w zakresie biografistyki, w: Historia historiografii i metodologia historii w Polsce i na Ukrainie, red. J. Maternicki, J. Pisulińska, L. Zaszkilniak, Rzeszów 2015, s. 214-230.

7 Na ten temat pisali m.in.: F. Bronowski, M. H. Serejski (1897-1975), „Kwartalnik Historii Nauki i Techniki”, R. XXI-3, s. 555-61; J. Maternicki J., Marian Henryk Serejski, w: Historycy warszawscy...; R. Stobiecki, Łódź jako ośrodek ... ; A. Wierzbicki, Przedmowa, w: M. H. Serejski, Europa a rozbiory Polski. Studium historiograficzne, Warszawa 2009, s. XIV-V. 
Do grona tych ostatnich, reprezentujących drugie, wykształcone już na UŁ pokolenie badaczy rodzimej historiografii, należeli: Franciszek Bronowski, Andrzej F. Grabski i Jerzy Włodarczyk ${ }^{8}$. Kolejną, trzecią generację tworzą uczniowie K. Śreniowskiej i A. F. Grabskiego - tragicznie zmarly Henryk S. Michalak ${ }^{9}$, Zbigniew Romek ${ }^{10}$ oraz Rafał Stobiecki.

Oparciem instytucjonalnym dla łódzkich badań z zakresu historii historiografii były początkowo prowadzone w Instytucie Historii przez M. H. Serejskiego, seminaria" . Po jego wyjeździe do Warszawy w 1965 roku łódzkie środowisko historyków historiografii wyraźnie się skurczyło. W Instytucie Historii samodzielnym pracownikiem naukowym, specjalizującym się w omawianej subdyscyplinie, była tylko Krystyna Śreniowska (Jan Adamus zmarł w 1962 roku, w 1973 na emeryturę przeszedł Józef

8 Franciszek Bronowski (1928-1992) ukończył studia socjologiczne i historyczne w UŁ. Doktorat uzyskał w 1964 roku na podstawie pracy Idea gminowtadztwa w historiografii polskiej (geneza i rozwój). Następnie zajął się analizą twórczości Adama Naruszewicza, niestety nie zdążył napisać rozprawy habilitacyjnej; zob. Stownik biograficzny historyków tódzkich..., s. 22.

Andrzej Feliks Grabski (1934-2000), uzyskał magisterium w 1955 roku na podstawie obszernej pracy poświęconej wojnom polsko-niemieckim za czasów Bolesława Chrobrego. W 1955 roku podjął pracę jako asystent w Zakładzie Historii Historiografii PAN w którym był zatrudniony do 1983 roku. Doktorat uzyskał w 1962 roku na podstawie dysertacji Polska X-XIII wieku w opinii wspótczesnych. Habilitował się w 1968 roku, podstawą habilitacji była rozprawa Polska w opiniach Zachodu XIV-XV wiek (druk 1969 r.). Na UŁ pracował od 1983 roku, w 1986 r. został kierownikiem Zakładu a następnie Katedry Historii Historiografii, którą kierował do śmierci; szerzej zob. R. Stobiecki, Wprowadzenie; w: A. F. Grabski, Dzieje historiografii, Poznań 2003, s. V-XIX; J. Kita, Andrzej Feliks Grabski (13 września 1934-26 czerwca 2000), w: Tenże, Luminarze nauki polskiej..., s. 73-76.

Jerzy Włodarczyk (1920-1997) historyk i bibliotekoznawca. Jeszcze jako student, w 1947 roku zatrudniony na stanowisku asystenta w Katedrze Historii Społecznej Starożytności i Średniowiecza kierowanej przez M. H. Serejskiego. W 1956 został adiunktem w Katedrze Historii Powszechnej Nowożytnej i Najnowszej. Następnie kierował Biblioteką IH UŁ (1961-79) oraz Biblioteką Uniwersytecką; zob. Stownik biograficzny historyków tódzkich..., s. 105-106.

9 Henryk Michalak (1947-1994), historyk historiografii i metodolog historii. Od 1975 roku asystent, potem adiunkt w Zakładzie Nauk Pomocniczych Historii a następnie w Katedrze Historii Historiografii. W 1983 roku uzyskał doktorat na podstawie rozprawy Józef Szujski 1835-1882. Światopogląd i działanie. Praca została opublikowana w 1987 roku. W kolejnych latach przygotowywał nigdy nieukończoną rozprawę habilitacyjną Związki historiograficzne polsko-czeskie 1795-1914; szerzej zob. Stownik biograficzny historyków..., s. 69-70.

10 Zbigniew Romek, absolwent historii na UŁ, następnie związany z Instytutem Historii PAN. Doktorat obronił w 1991 roku na podstawie dysertacji Olgierd Górka, Historyk w stużbie myśli propaństwowej (1908-1955) (druk1997 r.). Habilitował się w 2011 r.; podstawą habilitacji była wydana rok wcześniej praca Cenzura a nauka historyczna w Polsce 1944-1970. Obecnie jest zatrudniony w pracowni Dziejów Myśli Społecznej i Politycznej Instytutu Historii PAN.

11 Poza wychowankami/ współpracownikami Serejskiego, którzy niemal w całości (lub znacznej części) swą karierę naukową zwiążą z historią historiografii, we wspomnianych seminariach uczestniczyli również reprezentujący różne specjalności i dyscypliny badacze; m. in.: Tadeusz Błaszczyk, Władysław Bortnowski, Halina Evert-Kappesowa, Stefan Krakowski, Zofia Libiszowska, Ryszard Rosin, Bogumił Zwolski. W bliskim kontakcie z Serejskim, byli także historycy prawa; wspomniany J. Adamus oraz Stanisław Śreniowski. Filozofów reprezentowali Ija Lazari-Pawłowska i Tadeusz Pawłowski, archeologów - Andrzej Abramowicz i Tadeusz Poklewski. Serejski współpracował blisko również z gronem badaczy skupionych wokół Józefa Chałasińskiego, m. in. z Antoniną Kłoskowską); zob.: R. Stobiecki, Łódź jako ośrodek badań historiograficznych ..., s. 32 . 
Dutkiewicz)12. Śreniowska kontynuowała badania i prowadziła zajęcia oraz seminarium z historii historiografii, będąc związana instytucjonalnie z Pracownią Nauk Pomocniczych Historii (istniejącą od 1972 roku) następnie przekształconą (w 1975 r.) w Zakład Nauk Pomocniczych Historii, kierowany przez docenta Ryszarda Rosina ${ }^{13}$. We wspomnianym Zakładzie początkowo zatrudnieni byli również Henryk Michalak (od 1975 roku) oraz Rafał Stobiecki (od 1985 r.).

W ramach Instytutu Historii UŁ samodzielną jednostkę w której prowadzono badania z zakresu historii historiografii, powołano dopiero w 1986 roku, co zbiegło się $\mathrm{z}$ zatrudnieniem w Instytucie w pełnym wymiarze godzin, Andrzeja Feliksa Grabskiego ${ }^{14}$. Zakład, a następnie Katedra Historii Historiografii wyodrębniła się ze wzmiankowanego wyżej Zakładu NPH. Grabski kierował Katedrą do 2000 roku, po jego śmierci, kierownictwo objął Rafał Stobiecki. W wyniku dokonującej się w IH UŁ reorganizacji, 1października 2011r. doszło do połączenia Katedry Historii Historiografii oraz Zakładu Nauk Pomocniczych Historii w wyniku, którego powstała Katedra Historii Historiografii i Nauk Pomocniczych Historii, której kierownikiem pozostał Rafał Stobiecki. Obecnie w omawianej jednostce zatrudnionych jest 3 profesorów (w tym jeden zwyczajny) oraz 4 adiunktów ${ }^{15}$. Badania pracowników Katedry koncentrują się wokół: historii historiografii, teorii i metodologii historii, nauk pomocniczych ze szczególnym uwzględnieniem genealogii, heraldyki, sfragistyki, archiwistyki, geografii, kartografii oraz demografii historycznej. Jeśli chodzi o chronologiczny zakres zainteresowań; przeważa okres późnego średniowiecza po XIX, XX i XXI stulecie.

\section{BADAN1A}

Obecnie dzieje historiografii i myśli historycznej badają w Łodzi trzy osoby zatrudnione w Katedrze Historii Historiografii i Nauk Pomocniczych Historii Rafał Stobiecki, Jolanta Kolbuszewska i Anna Brzezińska.

12 Warto jednak zaznaczyć, iż mimo przeprowadzki Serejskiego do Warszawy, do jego śmierci w 1975 roku kontakt pomiędzy mistrzem, uczniami i niektórymi współpracownikami był utrzymany. Wspomniane grono spotykało się regularnie na prowadzonym przez Serejskiego w IH PAN, seminarium.

13 Na temat reorganizacji Instytutu, powoływania i likwidowania jednostek organizacyjnych pisał ostatnio W. Puś, Zarys historii Uniwersytetu Eódzkiego 1945-2015, Łódź 2015, s. 167-172.

14 A. F. Grabski od 1955 roku do 1983 r. pracował w Zakładzie Historii Historiografii PAN. Następnie został zatrudniony na UŁ. Pełnił funkcję wicedyrektora Międzyuczelnianego Instytutu Nauk Politycznych i kierownika Zakładu Historii Myśli Politycznej. W 1986 roku został kierownikiem Międzyinstytutowego Zespołu Metodologii i Historii Historiografii, związanego z MINP i IH UŁ objął również funkcję kierownika Zakładu a następnie Katedry Historii Historiografii; zob. J. Kita, Andrzej Feliks Grabski..., s. 74-5.

15 Skład osobowy Katedry Historii Historiografii i Nauk Pomocniczych Historii na dzień 1 X 2016 r.: prof. dr hab. Rafał Stobiecki (kierownik); dr hab. Marek Adamczewski, prof. UŁ; dr hab. Jolanta Kolbuszewska, prof. UŁ; dr Anna Brzezińska, dr Ilona Florczak, dr Piotr Szkutnik, dr Arkadiusz Rzepkowski. 
Rafał Stobiecki podejmuje zagadnienia z zakresu historiografii PRL-u oraz dziejopisarstwa polskiego na emigracji po 1945 r., teorii historii, relacji między pamięcią a historiografią, obecnością argumentacji historycznej we współczesnym dyskursie publicznym etc. Na jego dorobek składają się liczne monografie, artykuły i wydawnictwa źródłowe. Do najważniejszych należą: dysertacja doktorska - Historia pod nadzorem. Spory o nowy model historii w Polsce (II potowa lat czterdziestych - poczatek lat pię́́dziesiątych), Łódź 1993. Rozprawa habilitacyjna - Bolszewizm a historia. Próba rekonstrukcji bolszewickiej filozofii dziejów, Łódź 1998. Klio na wygnaniu. Z dziejów polskiej historiografii na uchodźstwie w Wielkiej Brytanii po 1945 r., Poznań 2005 oraz Historiografia PRL. Ani dobra, ani mądra, ani piękna... ale skomplikowana. Studia i szkice, Warszawa 2007 i Historycy polscy wobec wyzwań XX wieku, Poznań 2014. Stobiecki jest również współautorem/ współredaktorem publikacji: Stownik biograficzny historyków łódzkich, Łódź 2000 (oprac. J. Kita, R. Stobiecki); Jerzego Giedroycia rozrachunki $z$ historia i polityką. Studia i szkice w czterdziesta rocznicę "Zeszytów Historycznych”, red. S. M. Nowinowski, R. Stobiecki, Łódź 2005; Pamięć i polityka historyczna. Doświadczenia Polski i jej sąsiadów, red. S. M. Nowinowski, J. Pomorski i R. Stobiecki, Łódź 2008; „Należę do polskiej szkoty historycznej”. Studia i szkice ofiarowane prof. Jakubowi Goldbergowi z okazji odnowienia doktoratu na Uniwersytecie Łódzkim, red. R. Stobiecki, J. Walicki, Łódź 2010; Piotr Wandycz. Historyk-emigrant-intelektualista, red. M. Kornat, S. M. Nowinowski, R. Stobiecki, Bydgoszcz 2014 oraz W poszukiwaniu innej historii. Antologia tekstów opublikowanych na tamach periodyków Instytutu Literackiego w Paryżu, red. R. Stobiecki, S. Nowinowski, Łódź-Paryż 2015.

Jolanta Kobuszewska podejmuje badania z zakresu historii historiografii polskiej drugiej połowy XIX wieku, przełomu stuleci i okresu międzywojnia. W kręgu jej zainteresowań znajdują się przeobrażenia teoretyczno-metodologiczne zachodzące w rodzimej nauce, począwszy od schyłku XIX stulecia; kształtowanie się nowych subdyscyplin badawczych w obrębie historii oraz poszerzanie obszaru jej zainteresowań w sensie chronologicznym, problemowym i geograficznym. Badaczka uwzględnia również zewnętrzne uwarunkowania i mechanizmy wpływające na kształt nauki o dziejach. W obszarze jej zainteresowań znajduje się także problematyka z dziedziny biografistyki i źródłoznawstwa, historii codzienności oraz historii kobiet. Kolbuszewska ma w swym dorobku monografie: Mutacja modernistyczna w polskiej historiografii (przełom XIX i XX wieku), Łódź 2005 - praca doktorska oraz Tadeusz Korzon (1839-1918). Między codziennościa, nauką a stużbą narodowi, Łódź 2011 - rozprawa habilitacyjna. Jest współautorką opracowania Historycy a socjalizm. Polska lewica niepodległościowa spod znaku Klio, Łódź 2015 oraz współredaktorem monografii Historyk wobec źródet. 
Historiografia klasyczna i nowe propozycje metodologiczne, red. J. Kolbuszewska i R. Stobiecki, Łódź 2010.

Anna Brzezińska interesuje się polską i powszechną historiografią XX i XXI wieku ze szczególnym uwzględnieniem mediewistyki w interpretacjach francuskiej szkoły Annales oraz historiografii rosyjskiej XX stulecia. Podejmuje również refleksję mieszczącą się w nurcie historii antropologicznej. W grudniu 2015 roku uzyskała stopień doktora na podstawie pracy Spór o średniowiecze. Z rozważań nad tożsamością kulturowa Europy. Studium postaw: J. Le Goff, J. Kłoczowski, A. Guriewicz.

Poza osobami etatowo związanymi z Katedrą, badania nad dziejami historiografii podejmują również doktoranci/ doktorzy, wychowankowie Rafała Stobieckiego a od niedawna także Jolanty Kolbuszewskiej. Do grupy wypromowanych przez Rafała Stobieckiego doktorów należą: Artur Mękarski zajmujący się historiografią polską XX wieku ze szczególnym uwzględnieniem dorobku badaczy emigracyjnych, podejmuje również zagadnienia z zakresu historiozofii i teorii historii. W kwietniu 2008 roku uzyskał stopień doktora na podstawie rozprawy Polskie dziejopisarstwo na uchodźstwie wobec przemian w historiografii krajowej po 1945 roku. Wojciech Wendland badał refleksję historyczną Tatarów polskich. Pracę doktorską Myśl historyczna Tatarów polskich w II Rzeczypospolitej obronił w listopadzie 2012 roku. Sylwia Wielichowska w swej rozprawie doktorskiej podjęła problematykę związaną z historią kobiet. W listopadzie 2013 roku uzyskała stopień doktora na podstawie rozprawy Polska historia kobiet $w$ XX wieku. Początkirozwój - specyfika. Obecnie w ramach Studium Doktoranckiego pod opieką Rafała Stobieckiego i Jolanty Kolbuszewskiej, rozprawy doktorskie przygotowuje pięć osób. Andrzej Janicki, autor monografii Lew Nikołajewicz Gumilow (1912-1992) jako historyk cywilizacji rosyjskiej (Łódź 2011), pracuje nad tematem Pamięć drugiej wojny światowej we wspótczesnym rosyjskim dyskursie historycznym. Andrzej Czyżewski, mający w swym dorobku nagrodzone opracowanie Proces destalinizacji polskiej nauki historycznej $w$ drugiej połowie lat 50 XX wieku (Warszawa 2007), pisze rozprawę na temat Historia $w$ stużbie władzy - przeobrażenia oficjalnego obrazu okupacji $w$ Łodzi w okresie PRL. Studium z lokalnej polityki pamięci historycznej. Estera Flieger pracuje nad zagadnieniem Zagłady w historiografii polskiej do 1989 roku. Instytucje, sylwetki i interpretacje. Andrzej Kobak przygotowuje rozprawę Karol Potkański w życiu i nauce (1861-1907). Między tradycja a modernizacją. Ewa Janeczek-Jabłońska prowadzi prace nad Wizerunkiem kobiet władzy w historiografii polskiej doby rozbiorów. Niebawem ukaże się publikacja będąca efektem namysłu środowiska skupionego wokół Katedry dotyczącego relacji pomiędzy historią a pamięcią. Do końca 2016 roku Wydawnictwo Uniwersytetu 
Łódzkiego wyda monografię zbiorową pod red. J. Kolbuszewskiej i R. Stobieckiego zatytułowaną Historia i pamięć. Studia i szkice historiograficzne. ${ }^{16}$

Reasumując, łódzkie środowisko historyków historiografii podejmuje zagadnienia z zakresu polskiej i powszechnej nauki i myśli historycznej ostatnich trzech stuleci. Jego reprezentanci koncentrują się nie tylko na akademickim dyskursie naukowym, badają również pamięć i politykę historyczną oraz różne formy obecności przeszłości w przestrzeni publicznej. Poza klasycznie rozumianą historią historiografii, wspomniane grono podejmuje refleksję mieszczącą się w takich obszarach i nurtach badawczych jak: historia kobiet, historia codzienności, biografistyka, historia idei, historia antropologiczna, historia nauki i badania postkolonialne. Wspomniane studia podejmowane są we współpracy z wieloma krajowymi i zagranicznymi (europejskimi, amerykańskimi) ośrodkami i instytucjami naukowymi. W ramach badań statutowych, indywidualnych i grupowych projektów badawczych.

\section{DUDAKTYKA}

W Instytucie Historii UŁ zajęcia dydaktyczne z historii historiografii i metodologii odbywają się na studiach dziennych I, II i III stopnia (kierunek historia). Samodzielni pracownicy naukowi prowadzą seminaria licencjackie, magisterskie i doktorskie, w ramach których podejmowane są zagadnienia z historii historiografii, historiozofii, historii idei, teorii i metodologii historii. Od 2000 roku seminarium magisterskim kieruje Rafał Stobiecki, spod opieki którego, wyszło kilka wyróżnionych i nagrodzonych w ogólnopolskich konkursach, rozpraw ${ }^{17}$. Na studiach historycznych w ofercie dydaktycznej znajdują się również tzw. wykłady kursowe z historii historiografii. Na studiach licencjackich (drugi rok) w wymiarze 15 godzin odbywa się wykład Wprowadzenie do historiografii. Celem wspomnianego wykładu jest zaznajomienie studentów z zasadniczymi przemianami myślenia historycznego od czasów starożytnych do współczesności, pokazanie relacji między historią a innymi

16 Wspomniany tom składa się z dziesięciu tekstów, o dużej rozpiętości chronologicznej, od lat 80-tych XVIII wieku, po czasy wspótczesne. Autorzy - pracownicy Katedry oraz uczestnicy Studium Doktoranckiego, rozważają takie zagadnienia jak: wizerunki kobiet władzy w oświeceniowych syntezach dziejów Polski, upamiętnianie bohaterów narodowych w XIX stuleciu, wspomnienia o historykach zapisane w pamięci wspótczesnych, drogi polskich historyczek do samodzielności naukowej, lokalna politykę pamięci w czasach PRL-u, obrazy II wojny światowej w rosyjskich podręcznikach szkolnych oraz politykę historyczną i jej przetożenie na wspótczesna edukację szkolną.

17 Do wspomnianej grupy należą m.in. dysertacje: A. Czyżewskiego, Proces destalinizacji polskiej nauki historycznej $w$ drugiej potowie lat $50 \mathrm{XX}$ wieku (praca nagrodzona w konkursie im. Marcelego Handelsmana $w$ kategorii najlepszych pod względem metodologicznym prac magisterskich z zakresu historii, 2006 rok; M. Gielzak, Lidia i Adam Ciołkoszowie jako historycy socjalizmu polskiego, (praca dwukrotnie wyróżniona: w Konkursie im. Władysława Pobóg-Malinowskigo na Najlepszy Debiut Historyczny roku 2011 oraz w konkursie „Archiwum Emigracji”, organizowanym przez Uniwersytet Toruński oraz Kancelarię Senatu RP). 
dziedzinami humanistyki, prezentacja najważniejszych osiągnięć dyscypliny historycznej. Uzupełnieniem wykładu jest konwersatorium (15 godzin) w ramach którego, prezentowane są najważniejsze koncepcje dziejów Polski od końca XVIII wieku do początków XXI stulecia. Cykl zajęć kończy się egzaminem ustnym w sesji zimowej. Na studiach magisterskich (II rok) w wymiarze 30 godzin w semestrze zimowym odbywa się wykład Historia historiografii i metodologia historii. Celem tych zajęć jest prezentacja najważniejszych kierunków szeroko rozumianej historiografii współczesnej (m. in.: materializmu historycznego, dorobku szkoły Annales, studiów nad pamięcią, historii alternatywnych etc). Wydaje się to szczególnie ważne w dobie widocznych w społeczeństwie przemian w jego stosunku do przeszłości, specjalizacji i pluralizacji dokonującej się w naukach historycznych czy wreszcie zjawiska określanego mianem mediatyzacji wiedzy o przeszłości. Podobnie jak na studiach licencjackich wykładowi towarzyszy konwersatorium (30 godzin), podczas którego studenci mają okazję pogłębić swą wiedzę dotyczącą modeli i wzorców uprawiania historii w XX wieku. Analizie poddawane są takie nurty/ kierunki/ subdyscypliny jak: historia kobiet, historia antropologiczna, oral history, psychohistoria, studia postkolonialne etc. Cały cykl zajęć kończy się egzaminem ustnym.

Poza wykładami z historii historiografii na studiach historycznych I stopnia oferowany jest (na zasadzie wyboru) trzydziestogodzinny wykład monograficzny Metodologia historii. Ma on dwa główne cele - teoretyczny, polegający na zaznajomieniu studentów z podstawowymi pojęciami z zakresu teorii historii (np. czas, przestrzeń, narracja, źródło) oraz praktyczny, zwracający uwagę na ich zastosowanie w analizie wybranych zagadnień z przeszłości. Wykład kończy się zaliczeniem $\mathrm{w}$ formie pracy pisemnej.

Wykładom kursowym i monograficznym towarzyszą kursy specjalizacyjne $\mathrm{w}$ formie konwersatoriów. W każdym roku akademickim w ramach Katedry realizowane są 4 trzydziestogodzinne kursy w semestrze zimowym i cztery w semestrze letnim (łącznie na I i II stopniu studiów historycznych). Mniej więcej połowa z nich poświęcona jest szeroko rozumianej historii historiografii. W latach ubiegłych odbyły się m.in. zajęcia poświęcone: Rewolucji Francuskiej w historiografi szkoły Annales; Obrazowi średniowiecza i chrystianizacji Europy w historiografii PRL, problemowi Pisania i rozumienia historii czy Wspótczesnym metodom uobecniania historii.

Treści z zakresu metodologii, teorii historii i epistemologii oraz historiozofii, przekazywane są studentom również podczas zajęć ze wstępu do badań historycznych oraz monograficznego wykładu z filozofii (I rok studiów licencjackich).

Jeśli chodzi o wykorzystywane w procesie dydaktycznym metody, dominują metody podające i problemowe; takie jak konwencjonalny wykład informacyjny, 
wykład problemowy oraz wykład konwersatoryjny. Ten ostatni połączony z aktywnością słuchaczy, skierowany bywa na rozwiązanie problemów teoretycznych lub praktycznych. Największą jego wartością jest udział studentów w poszukiwaniu odpowiedzi, docieraniu do „prawdy” oraz obrona własnego stanowiska. Wykład konwersatoryjny najlepiej sprawdza się w niewielkich grupach. Masowość kształcenia, duża liczebność uczestników i ograniczony czas jakim dysponujemy, często zmusza nas do stosowania mniej efektywnego, wykładu informacyjnego. Mając świadomość tego, jak przebiega proces uczenia się dorosłych, zgodnie z koncepcją Davida Kolba (Experiential Learning Model) ${ }^{18}$, podczas zajęć konwersatoryjnych staramy się sięgać do tzw. metod poszukujących (active learning); m.in.: tzw. burzy mózgów, dyskusji panelowej, prezentacji, studium przypadków, metody stolików eksperckich, dyskusji wokół referatów etc. Sięgamy również po metody eksponujące, wiążące się z wykorzystaniem filmu, ekspozycji muzealnej i innych ${ }^{19}$.

Podczas zajęć wykorzystujemy różnorodne środki dydaktyczne; zarówno wzrokowe, słuchowe, jak i wzrokowo-słuchowe ${ }^{20}$. Chętnie sięgamy po nowoczesne środki ikonograficzne, audiowizualne, prezentacje multimedialne, sieć internetową. Nie zaniedbujemy jednak klasycznej pracy polegającej na analizie tekstu źródłowego czy przestrzennej (graficznej) prezentacji części składowych pojęć i definicji, przy wykorzystaniu tablicy czy flipchartów etc. Generalnie staramy się korzystać z bogatej oferty dostępnych lub specjalnie przygotowanych, środków; materiałów edukacyjnych, łącząc akademicką tradycję z nowoczesnością.

18 Kolb udowadnia, iż do skutecznego uczenia się niezbędna jest zamiana roli z obserwatora w uczestnika, a dalej z bezpośredniego zaangażowania na bardziej obiektywne, analityczne spojrzenie; szerzej zob. I. Kazimierska, I. Lachowicz, L. Piotrowska, Uczenie się dorostych - cykl Kolba, Warszawa2014.

19 Na zajęciach analizowane były m. in. takie filmy jak: Shoah C. Lanzmanna, Aleksander Newski S. Eisensteina czy Powrót Martina Guerre, Daniela Vigne. Jeśli chodzi o ekspozycje muzealne, przy okazji realizacji zagadnień związanych z historią codzienności studenci analizowali wystawę W kuchni pani Goldbergowej (Skansen przy Muzeum Włókiennictwa w Łodzi); historia rzeczy została przybliżona dzięki wystawie Atlas nowoczesności (Muzeum Sztuki 2 w Łodzi).

20 Zob.: Cz. Kupisiewicz, Podstawy dydaktyki ogólnej, Warszawa 1988, s. 213-16. 